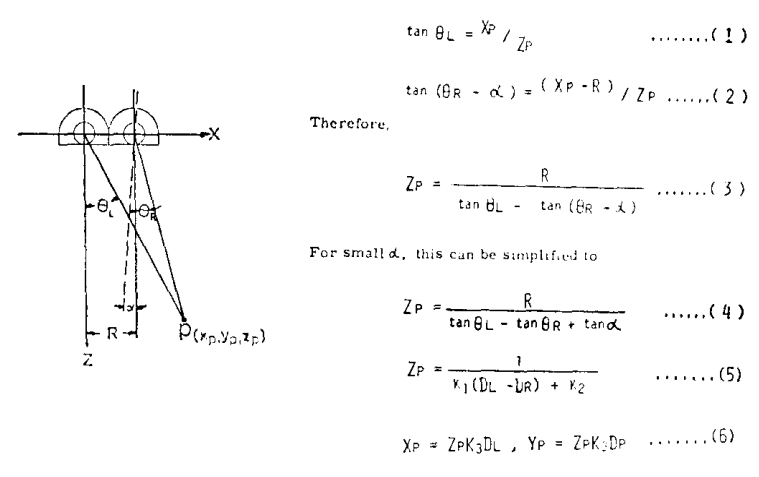

図 3 計測点の座標値の求め方

び座標值の求め方を示す，Rは左右の対物レン ズの中心間の距離である. 式(1) (6!の中で実際 に用いるのは式(5)，(6)である。式の中のDL， D Rは左右の視野について，それぞれの中心か ら計測点までのX方向の距離を示し，DPは左 視野についてその中心から計測点までのY方向 の距離である， $\mathrm{K}_{1}, \mathrm{~K}_{2}, \mathrm{~K}_{3}$ は常数で，あらか じめわかった距離におかれた方眼紙を写真撮影 して求めて㧍く。

方眼紙を使って種々計測した結果, 対物レン
ズから計測点までの距離Zの測定誤差は， 6〜 $10 \mathrm{~cm}$ の距離で $2 \mathrm{~mm}$ 以下, 方眼紙上の長さの 測定誤差は，1〜1. $5 \mathrm{~cm}$ の長さで $0.3 \mathrm{~mm}$ 以下 であった。ただし計測点が視野の周辺に近くな ると誤差はさらに大きくなると考えられる。

成人男子 11 名，成人女子 17 名について，呼吸 時の声帯（いわゆる膜様部）の長さを計測し た．声帯長にはかなりの個人差があり，成人男 子で $10.8 \sim 19 \mathrm{~mm}$, 成人女子で $8.2 \sim 13.2 \mathrm{~mm}$ の間に分布した。男女の分布にある程度の重な りはあるが，全体として男子の方が女子ょり声 帯は長い。身長と声帯長との相関は明らかでな い. 頸囲と声帯長には正の相関がみられるよう である，また男子に执いて，声域の下限の低、 者は声帯が長い傾向がみられた。

発声時には低音発声に比べて高音発声で声带 が長くなることが示された。また発声時に比べ て呼吸時の方が声帯が長いことも示された。さ らに呼吸時に長い声帯をもつ者は，発声時にも 長い声帯であることも示された。

\title{
16. 最近開発されを発声機能検査装置の使用経験
}

\author{
鯨井和朗* 大石公直* 沢木修二* \\ 廣 瀬 肇*2
}

各種の音声障害をもつ症例の診断，あるいは 治療効果の判定にあたっては, さまざまな検査 がある，われわれの臨床で現在行われている検 查には，患部を直接に観察する検查として，間 接喉頭鏡検查，喉頭ファイバースコープ，スト ロボスコープ等があり, 音声自身や発声の機能 を客観的にとらえる検査として，声の高さ，強 さ，質あるいは肺活量，発声持続時間，発声時 呼気流率の測定がある。これら個々の検查項目 に対しては以前から多数の報告があり, 検查法 も確立しているが，特に機能検查としていくつ

* 横浜市立大学耳鼻咽喉科

$*_{2}$ 東京大学音声言語医学研究施設
かの項目を組み合わせて同時に相互の関係を示 すような方法は報告も少なく，その意義や結果 の判定について明確な基準がない.

このたび医療保健に音声機能検査として，音 域検查, 声の強さ, 発声時呼気流率, 発声持続 時間の測定が適用されたこともあり，同時に測 定することの意義が注目され始めている．われ われはこの目的で製作された永島製発声機能検 查装置 PS-77を用い，多数例を経験したので, この測定機の特徴について考察した.

この装置の外観は図 1 に示すと㧍りで，音圧 はエレクトレットコンデンサマイクロホンを用 いて測定され，呼気流率は熱線流量計を用いて 測定されている. 基本周波数は, 熱線流量計の 


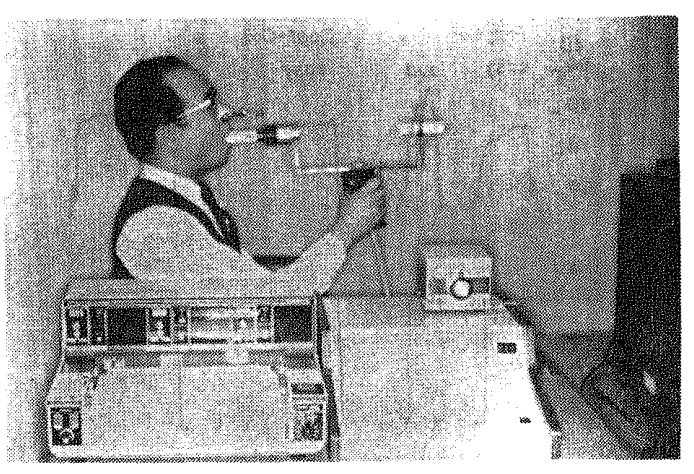

図1

出力よりフィルターによって倍音成分を除去し て求めている。熱線流量計は直線性, 再現性, 過度応答にすぐれ，周波数応答も DCより数 10 $\mathrm{kHz}$ におよんでいる。

記録には $3 \mathrm{ch}$ ペンレコーダを用い，毎分 60 $\mathrm{cm}$ の紙送り速度で, 声の大きさ, 声の高さ, 呼気流率の時間的変化を記録した．また症例に よっては 2 台の X-Y レコーダを用い，声の大 きさを変化させた時に基本周波数や呼気流率が どのように変化するかを表示させた。

発声させるにあたっては，マウスピースを用 いて/ア/と言うつもりで楽な声から始め, で きるだけ小さい声, できるだけ大きい声を，声 の高さは指定せずに 3 回ずつ記録した，次いで 声の大きさは指定せず，最も低い声，最も高い 声を記録した。最後に楽な声で最大吸気後にで きるだけ長く発声させ, 持続時間を測定した.

検查の対象は，何らかの音声障害をもって， われわれの音声外来を訪れた男女76例（平均年 龄46歳）と対照とした健康な成人男女各 10 名で ある。疾患別の内容は表 1 に示す。

この装置を用い, $3 \mathrm{ch}$ ペンレコーダで記録 した正常者の代表的な波形を図 2 に示す.上か ら順に声の強さ, 基本周波数, 発声時呼気流

表 1

\begin{tabular}{|c|c|c|c|}
\hline 疾 患 性 別 & 男 & 女 & 計 \\
\hline 声帯ポリープ & 19 & 8 & 27 \\
\hline 声 帯 結 節 & 2 & 10 & 12 \\
\hline 喉 頭 癌 & 6 & 1 & 7 \\
\hline 声 带 麻 㾝 & 9 & 3 & 12 \\
\hline そ $の$ 他 & 12 & 6 & 18 \\
\hline 計 & 48 & 28 & 76 \\
\hline
\end{tabular}

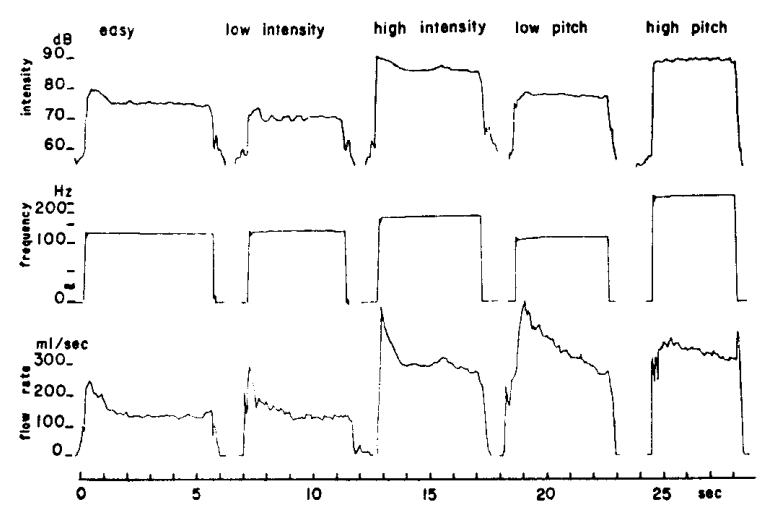

図 2
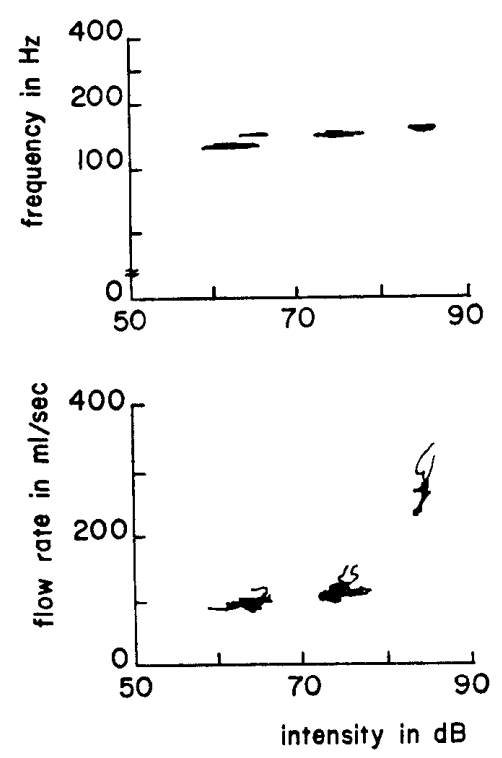

困 3

率, 左から順に楽な発声, 小さい声, 大きい 声, 低い声, 高い声となっている。

各波形をながめると，声の大きさを示す曲線 は，小さな波の乗った比較的平坦な曲線とな る. 基本周波数を示す曲線は，ほとんど変動し ない直線となるまをた呼気流率を示す曲線は小 さな波の乗った曲線となるが, 多少の変動がみ られ，特に発声開始より約 1 秒間は安定しな '.

これら 3 つの検查項目間の関係を，声の大き さを変化させた時について調べると, 図 2 の例 では小さい声と楽な声では流量, 周波数ともに あまり変化はないが，大きい声では高さを指定 しなかったため基本周波数が上昇し，また呼気 流率も多くなっている.この関係は, 図 3 に示 すように $3 \mathrm{ch}$ ペンレコーダの変わりに 2 台の

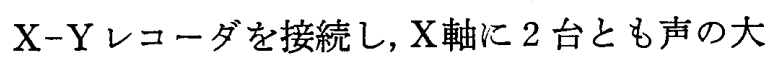



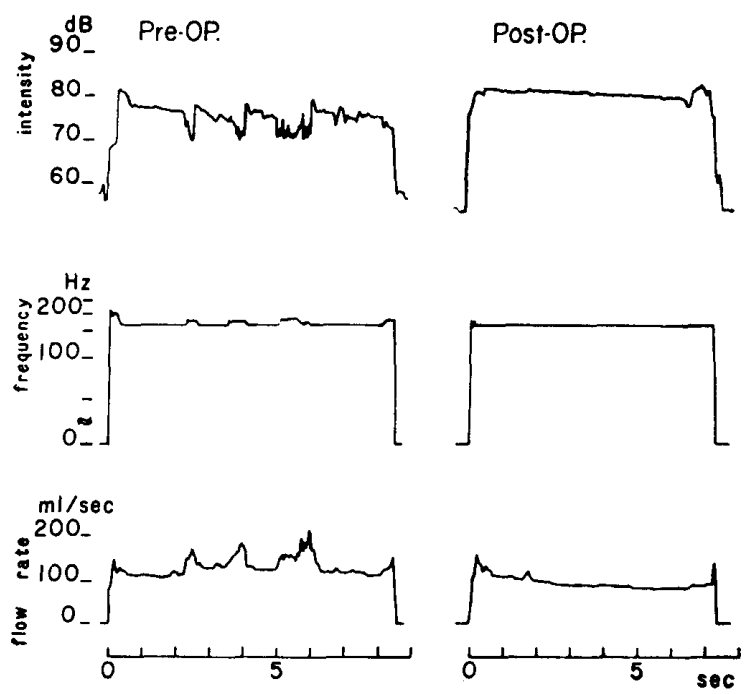

図 4

きさを，Y軸に 1 台は基本周波数，他は呼気流 率を入力して図を描かせるとさらにはっきりす る. 図 3 に示した例では声の大きさの増大に伴 い, 基本周波数が上昇し, 呼気流率は大きい声 で増大している，一般には声を大きくすると基 本周波数はやや増加し, 呼気流率は大きい声で 増加する傾向にあった。

声の高さを変化させた時には，声の大きさを 特に指定しなかったため，一般的には声の大き さも高さとともに大きくなる傾向があった。こ れに反して呼気流率は個人によりさまざまな変 化を示し，特別な傾向は認められなかった。

図 4 は声帯ポリープのあった26歳男性に, 楽 に/ア/と発声させて記録したものである。左 側は手術前, 右側は喉頭顕微鏡下声帯ポリープ 切除術を行い，1 1 月後に再検査したものであ る. 術前のものでは正常者のものと比べてどの 曲線も凹凸が増している，各波形をみると，声 が小さくなったところで基本周波数がゆらぎ， 同時に呼気流率も増加している，ストロボスコ ープでの所見と合わせて考えると，ポリープに よる声帯振動の一過性の障害と, 声門閉鎖不全 がみられたときの波形を示しているものと推測 された. 術後には, これらの所見が消失し, 各
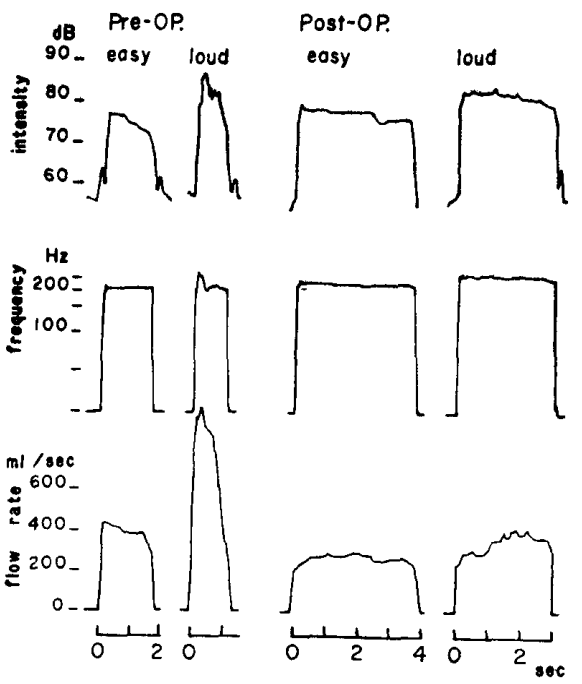

図 5

曲線ともになめらかになって, 治療の効果がよ くわかる.

図 5 は一側反回神経麻㾴の例（53歳女性）の 曲線である. 左の 2 列は術前のもので, 楽な発 声では声の大きさ，基本周波数ともに正常者と あまり変化ないが，呼気流率は著明に增大し， 発声持続時間も短縮している，大声を出そうと すると, 呼気流率は極端に増大し, 喉頭での調 節が麻㾝のためできなくなっていることを示唆 している.この症例に，シリコンブロックによ る声帯正中固定術を行い，1 カ月後に測定した 結果が図 5 右の 2 列で，大声を出したときの呼 気流率と発声持続時間の改善がよくわかる.

以上示したように，この装置は疾患の診断に は向かないが，声の大きさ，基本周波数，呼気 流率，発声持続時間を関連させてみることによ り，声帯振動および声門の閉鎖状態をある程度 推測することが可能で, 特に治療効果を判定す る上では非常に有用であることがわかった。 ま た個々の検查を別々に行うわずらわしさもな く，機械も小型で扱いやすいため，いつでも手 軽に検査できることが特徴となっている，乙か し欠点として，他の方法同様基本周波数抽出時 に多少の難点があった。 